DERLEME MAKALESİ / REVIEW ARTICLE

Atıf için /for cited: Silsüpür, Ö. (2021). Halkla İlişkiler ve Medya: Araç ve Yöntemler Üzerine Bir Çalı̧̧ma. Journal of Vocational and Social Sciences of Turkey, Yll: 3, Sayl: 5, Nisan 2021, s.66-78.

\title{
HALKLA İLIŞKILER VE MEDYA: ARAÇ VE YÖNTEMLER ÜZERİNE BİR ÇALIŞMA
}

\section{Özer SILLSÜPÜR*}

\begin{abstract}
ÖZET
Halkla ilişkiler, kurumsal amaçlara ulaşmak için iç ve dış hedef kitlelerde doğruluk esasıyla hareket edilen, karşılıklı anlayışın geliştirildiği planlı iletişim çalışmalarını ifade etmektedir. Kurumların hedef kitleler zihinlerinde olumlu şekilde algılanmasına katkı sağlayan halkla ilişkiler faaliyetleri, medya ile kurulacak iletişism açısından da önem taşımaktadır. Halkla ilişkiler birimlerinin medya ile kuracağı iletişimde samimiyet, dürüstlük, açıklık gibi özelliklerin taşınması ve bu özelliklere sadık kalınarak diyalogun sağlam temellere oturtulması gerekmektedir. Ayrıca halkla ilişkiler birimlerinin medya ile kuracağı iki yönlü iletişimle, gerek kurumun kendini kamuoyuna tanıtmasına gerekse de kamuoyunun kurum hakkında bilgi sahibi olmasına ve kurumu tanımasına da katkı sağlanmaktadır. Çalışmada, kurumların iç ve dış hedef kitleler açısından halkla ilişkilerden nasıl yararlanacağı, halkla ilişkilerde kullanılan araç ve yöntemler, medya ile ilişki kurulurken yararlanılan etkinlikler literatür taraması yapılarak açıklanmıştır. Bu bağlamda çalışma, halkla ilişkiler ve medya ilişkileri bağıntısını kurmak kaydıyla Türkiye'de halkla ilişkilerin kuramsal gelişimine katkı sağlamayı amaçlamaktadır.
\end{abstract}

Anahtar Kelimeler: Halkla İlişkiler, Medya, Medyayla İlişkiler, Araç ve Yöntemler.

JEL Kodları: L82, M30, M39.

\section{PUBLIC RELATIONS AND MEDIA: A STUDY ON TOOLS AND METHODS}

\begin{abstract}
Public relations, in order to reach corporate purposes in internal and external target group acted on the basis of trueness, refers to planned communication studies that enchances mutual understanding. Public relations activities which contribute to the perception of corporates on the target groups mind in a positive way, also imporant in terms of the relations with media. Public relation units establishing a communication with media should contain qualities such as sincerity, honesty, clarity and stick to these qualities to build on firm ground. Also, public relations units with the two-way connection they are going to make with media contributes to both corporation's introducing themselves to the public and public's to have knowledge about the corporation and recognize it.In this study, how corporates use public relations in terms of internal and external target groups, methods and tools used in public relations, explained with the activity used while the relations are established with the media are explained by a literature review. In this context, this study is to establish a connection with public relations and media relations while contribute to public relations' theoretical development in Turkey.
\end{abstract}

Keywords: Public Relations, Media, Media Relations, Tools and Methods.

JEL Codes: L82, M30, M39.

\footnotetext{
* (D) Trabzon Üniversitesi, İletişim Fakültesi, Halkla İlişkiler ve Reklamcılık Bölümü, Öğr.Gör.Dr., ozer.silsupur@gmail.com
} 


\section{GíRiș}

Illetişim, kaynak ve hedef arasında türlü araçlar vasıtasıyla gerçekleșen süreç olarak tanımlanmaktadır. İletişim açısından bu süreç içerisinde kaynağın ilettiği mesajların hedeflenen kitlede karşıllı̆̆ını bulup bulmadığı, mesajların doğru alınıp alınmadığı anlaşılmakta ve öğrenilmektedir. İletişimin insan hayatındaki önemi ve etkisi pek çok yerde görülmektedir. Bireyler arasında ve sosyal ilişkilerde önemli olan iletişim (Silsüpür, 2016: 726), halkla ilişkiler çalışmalarının temelini oluşturmaktadır. İki yönlü iletişim sürecini ifade eden halkla ilişkiler faaliyetleri (Kocabaş vd., 2002: 49), kurum yönetimlerinin sonuca ulaşmak için tercih ettiği etkili bir araçtır. Toplum içinde yaşayan her kişi ve kurumun çevresiyle kurduğu ilişkileri bir amaç doğrultusunda gerçekleştirmesi ve planlı sürdürmesi mecburidir (Gürüz, 1993: 1). Bu sebeple bir yöneticilik becerisi olan halkla ilişkiler toplumla olan bu iletişimi kurmada, düzenlemede ve geliştirmede kitle iletişim araçlarını, medyayı ve sosyal mecraları kullanarak önemli bir görevi üstlenmektedir. Halkla ilişkilerin kamu faaliyetleri, kurumsal ilişkiler, yatırımcı ilişkileri, tanıtım, basın danışmanlığı, basınla ilişkiler gibi çok farklı görevleri bulunmaktadır. Halkla ilişkilerin bu her bir işlevi kuruluşların doğal şartlarından doğan ve çeşitli ihtiyaçlara cevap veren iletişim fonksiyonlarıdır (Barry, 2003: 16). Kişi ve kuruluşlar üstünde çok büyük etkisi olan medya, belirli konularda kamuoyu oluşturmada, kamuoyunun gösterdiği reaksiyonu olumlu veya olumsuz istikamette etkilemede önemli ve etkili bir güce sahiptir (Göksel, 2010: 114). Kuruluşla alakalı haberin veya bilginin medyada yer alması için haberin yenilik taşıması, merak uyandırıcı olması, izleyicileri ilgilendirmesi, yayınlanma zamanına dikkat edilmesi, uygun iletişim araçlarıyla ve vaktinde medyaya ulaştırılmasına hassasiyet gösterilmesi gerekmektedir. Halkla ilişkiler çalışanlarının basın toplantısı düzenleme, basın bildirisi kaleme alma, medya çalışanlarına geziler düzenleme gibi faaliyetleri medya ilişkileriyle olan bağın doğal sonucu (Kalender, 2012: 10) ve olmazsa olmazlarındandır.

$\mathrm{Bu}$ çalışmada halkla ilişkiler disiplini ve medya ele alınarak, halkla ilişkilerin medyayla olan ilişkisinde kullanılan araç ve yöntemlerin neler olduğunun belirlenmesi amaçlanmış ve bu doğrultuda literatür taraması yapılmıştır. Bu bağlamda çalışma temel olarak iki bölümden oluşmaktadır. Birinci bölümde halkla ilişsiler, halkla ilişkilerde kullanılan araç ve yöntemler ele alınmıştır. İkinci bölümde ise halkla ilişkilerin medyayla ilişkisi, bu ilişkiyi kurmada ve geliştirmede kullanılan etkinlik ve uygulamalar açıklanmıştır. Bu çalışma, Türkiye'de halkla ilişkilerin kuramsal gelişimi açısından halkla ilişkiler disiplini ile medya arasındaki ilişkinin kurulmasında kullanılan araçları, yöntemleri, etkinlikleri ve uygulamaları bir düzen ve akış içerisinde ele alması yönüyle önem taşımaktadır.

\section{HALKLA İLIŞKILLER VE HALKLA İLIŞKİLERIN TEMEL İLKELERİ}

Halkla ilişkilerin başlangıcı olarak kabul edilen 20. yüzyıldan itibaren gerek teori gerekse de uygulama açısından halkla ilişkilerin esasını oluşturan özelliklerin ve ana amaçların geniş boyutta kabul edilen bir tanımlaması yapılamamıştır (Okay ve Okay, 2001: 1). Bu açıdan halkla ilişkiler kavramını tanımlamak ve halkla ilişkilerin ne ifade ettiğini anlamakta fayda vardır. Öncelikle halkla ilişkiler kavramı çeşitli yazarlar tarafından faklı şekillerde tanımlanmıştır. Bu açıdan bir iletişim süreci olan halkla ilişkileri ifade ederken net ve kesin bir tanım belirtmemiz pek mümkün değildir. Bu farklı tanımlamalar aslında halkla ilişkilerin geniş bir uygulama alanına sahip olmasından, birçok bilim dalından beslenmesinden ve çok yönlülüğünden kaynaklanan olumlu bir yaklaşımdır.

Gerek toplumsal sorumluluk icabı gerek ticari ilişkiler sonucu günlük hayatın içinde gittikçe daha fazla yer alan ve önem kazanan halkla ilişkiler kavramı (Yıldız, 2010: 24), bir kurumun sunduğu hizmetin geliştirilmesi için yürütülen ve kamuoyunu etkilemeye yönelik tüm ilişki biçimlerini kapsayan planlı çabalara verilen isimdir (Ertekin, 1995: 9).

Halkla ilişkiler; yönetimin belirlediği politikaların halka benimsetilmesi, faaliyetlerin sürekli ve eksiksiz biçimde duyurulması, yönetime karşı pozitif bakış açısı oluşturulması ve buna karşı halkın da yönetim için ne düşündüğünün, yönetimden ne beklediğinin bilinmesi ve halkla işbirliği yapılmasıdır 
(Kocabaş vd., 2002: 45-47). Bu bakımdan halk, yönetimin aldığı kararlara ve düşüncelere tepkide bulunmakla kalmamakta, aynı zamanda yönetimin eylemde bulunamadığı meselelerde de onu harekete geçirmek için etkide bulunmaktadır. Dolayısıyla halkla ilişkiler; yönetimden halka ve halktan yönetime giden iki yönlü bir ilişki sürecini ifade etmekte (Tortop, 1998: 24), çevre ile olan ilişkilerin organize bir şekilde geliştirilmesi ve kuruluş açısından pozitif neticeler elde edilmesi için gerçekleştirilen faaliyetleri kapsamaktadır (Gürüz, 1993: 1).

Halkla ilişkiler; kurum için kamuoyunu anlama, değerlendirme ve geliştirmenin yanında yönetimin de amaçlarını, politikalarını, görevlerini ve kurumun işleyişine ait bilgileri vatandaşlara aktararak yönetimde etkinliği de artırmayı sağlamaktadır (Sezgin, 2007: 3).Bu nedenle kurumla halk arasında gerçekleşen iletişim yönetimi sürecini ifade eden halkla ilişkiler (Grunig ve Hunt, 1984: 6), bir kurumun başarı ya da başarısızlığının çeşitli gruplarla olan ilişki ve karşılıklı yararına bağlı olarak sürdürülen bir yönetim işlevini (Cutlip vd., 1994: 6)de açıklamaktadır.

Halkla ilişkiler; kurumların tüketiciler, çalışanlar, dağıtıcılar gibi farklı hedef gruplarına yönelik gerçekleştirdiği stratejik iletişim faaliyetleridir (Peltekoğlu, 2004: 6). Halkla ilişkiler; kurumların toplumsal isteklere cevap vermelerini kolaylaştırarak (Tengilimoğlu, 2001: 3), hedef kitlelerle karş1lıklı çıkar temelinde ve doğru bir iletişim kurulmasını sağlayarak kurumla ilgili pozitif imaj ve destek oluşturmaktadır (Asna, 2006: 17). Bu sebeple halka ilişkilerin temel amacı, kamuoyunda kurumla ilgili olumlu algı ve hüküm sağlamaktır (Aydede, 2002: 13).

Yapılan tanımlarda dikkat çeken ortak özellik, halkla ilişkilerin temelinde iletişim unsurunun olmasıdır (Kazancı, 2007: 72). İki yönlü iletişime, iyi niyete, karşılıklı fayda ve anlayışa, sosyal sorumluluğa, stratejik ilişki ya da stratejik iletişime odaklanan tanımlar, halkla ilişkilerin özünü yansitabilecek niteliktedir (Kalender, 2011: 27).

Kurumların kamu yararını koruyarak uluslararası alanda sempati ve iyi niyeti kazanmak için başvurdukları, kurumsal çalışmaların tüm sosyal yapı üzerinde meydana getireceği etkilerin sosyal sorumlulukla yapılmasını içeren, kamuoyunu etkileme ve kamuoyundan da etkilenme süreci (Erdoğan, 2014: 18) olan halkla ilişkilerin kendine has temel ilkeleri bulunmaktadır. Halkla ilişkiler etiği olarak da ifade edilen ilkeler şunlardır: İki yönlü süreç, dürüstlük, inandırıcılık, yineleme, sabırlı çalışmak ve şeffaflık (Toptop, 1998: 24; Sezgin, 2007: 67-69).

\section{HALKLA İLIŞKILERİN AMAÇ VE GÖREVLERİ}

Kâr amacı gütmeyen kamu kurumlarında ve kâr amacı güden özel kuruluşlarda halkla ilişkilerin amaçları ve görevleri farklılık gösterebilmektedir. Devlet kurumlarında ve özel kuruluşlarda halkla ilişkilerle hedeflenen amaçlar her ne kadar farklılık gösterse de, bunlar temelde aynı amaç doğrultusunda hareket etmek yani hedef kitlelerin dikkatini çekmek amaçlıdır.

Halkla ilişkilerin amaçları arasında kurumla ilgili olumlu yazıların basında yayınlanmasını sağlamak ve kurulan iletişimin aktif olarak yönetilmesinde rol oynamak, marka oluşturmada başvurulan yaratıcı ve stratejik uygulamaları geliştirmek, seminerler, sergiler ve çeşitli etkinlikler vasıtasıyla potansiyel müşterilere ulaşmak yer almaktadır (Barry, 2003: 16). Bunlara ilave olarak; toplum ile iyi ilişkiler kurulması, kurumsal yayınların yapılması, kamuoyu oluşturma ve kamuoyunun etkilenmesi, öneri ve danışmanlık hizmetlerinin verilmesi, kurum hakkında yayın yapılması, kurum imajına yönelik reklamlar kampanyaları yürütülmesi ve sosyal içerikli programlar düzenlenmesi halkla ilişkilerin amaçlarındandır (Tuna ve Tuna, 2007: 68). Dolayısıyla bu amaçların gerçekleştirilmesi için halkla ilişkiler örgütlerinin yararlandığı olanak ve kaynaklar şunlardır (Tortop, 2009: 11):

- Uygun görülen haberleri basına ulaştırmak,

- Basını takip etmek, gerekli görülen yazı ve resimleri kesip muhafaza etmek,

- Bülten yayımlamak,

- Halkı bilgilendirici kitap ve broşürler yayımlamak, 


\section{TÜRKIYE MESLEKI VE SOSYAL BILIMLER DERGISI}

- Toplumun şikâyetlerini dinlemek,

- Meclis çalışmalarını ve kongrelerini izlemek,

- Basin toplantıları düzenlemek,

- Radyolarda özel programlar hazırlamak,

- Tören ve özel günlere basın davet etmek,

- Filmlerden faydalanmak.

\section{HALKLA İLIŞKILERDE KULLANILAN ARAÇ VE YÖNTEMLER}

Kitle iletişim araçları teknolojilerinin özellikle günümüzde hızlı biçimde gelişmesi, bireylerin dünyanın her yerindeki meselelerden hemen haberdar olmasına, çeşitli konular üzerinde daha basit ve çok az maliyetle bilgi sahibi olmasına imkân vermiştir (Kalender, 2005: 106).

Halkla ilişkiler, gelişen teknolojilerin olanaklarından istifade etmekte ve hedef kitleleriyle her mecrada iletişim sürdürmektedir. $\mathrm{Bu}$ nedenle halkla ilişkilerin hedef kitleleriyle sürdürdügü iletişimde kullandığı araçları bilmek önem taşımaktadır. Halkla ilişkilerin kullandığı birçok araç vardır. Bunlar yazılı ve basılı araçlar, sözlü araçlar ve görsel-işitsel araçlar olarak ayrılmaktadır.

İletişim araçları seçilirken, iletilmek istenen mesajın türüne göre seçilmektedir. Çünkü her zaman yazılı ya da sözlü araçlar etkili olmamakta, bazen de bunların görsel ve işitsel araçlarla desteklenmesi gerekmektedir. Bu iletişim araçları şunlardır (Tengilimoğlu vd., 2009: 229):

- Yazılı ve Basılı Araçlar: Dergiler, gazeteler, afişler, ilan tahtaları, bültenler, broşürler, el ilanlar1, y1llık raporlar vb.

- Sözlü Araçlar: Telefonla görüşme, yüz yüze konuşma, konferanslar, seminerler, sempozyumlar, toplantılar, paneller vb.

- Görsel ve İşitsel Araçlar: Televizyon, radyo, sergi ve fuarlar, yarışmalar, törenler, kokteyller, festival ve şenlikler vb.

Halkla ilişkilerin kullandığı bu araçların bazılarını açıklamak ve halkla ilişkiler açısından nasıl kullanıldığına bakmak gerekmektedir.

\subsection{Yazılı ve Basılı Araçlar}

Gazeteler: Kitle iletişim araçlarının en önemlilerinden birisi olan basın en kolay manada "gazete", uzak ve yakın geçmişin veya günün haber ve meselelerinin sunulmasında, fikir ve kanaatlerin geniş kitlelere ulaştırılmasında, halkın ilgisini ülkenin önemli konuları üzerine çekmede ve okuyucuların genel kültürlerini artırmada çok etkili görev üstlenmektedir (Bektaş, 2002: 99). Bilgi ve haber kaynağ1 olarak televizyondan daha zengin olan gazeteleri okuyan bireyler, televizyon izleyen kişilere kıyasla toplumda neler olduğunun daha çok farkındadırlar (Devran, 2004: 235).

Radyo ve televizyona göre en entelektüel iletişim aracı olan gazetenin, elektronik medyanın kaybolan mesajları karşısında üstünlüğü sadece okurun istediği zaman ulaşabilmesi değil, aynı zamanda televizyon ve radyo tarafından genellikle gelişigüzel ele alınan konuları detaylarıyla ve yorumlarla birlikte sunmasidır (Kazaz, 2007: 222). Ayrıca yazılı basının avantaj1, olayları daha derinlemesine irdeleyebilme, eleştiri, yorum ve haber yoluyla farklı görüşleri bir arada bulundurabilmesidir (Çobanoğlu, 2007: 113).

Halkla ilişkiler aracı olarak gazetelerden yararlanırken gazetelerin belirli konulara öncelik verdiklerini, bu önceliğin kendi ilkelerinden kaynaklandığını unutmamak gerekmektedir. Örneğin fikir gazeteleri aydınlara, spor gazeteleri gençlere ve spor kamuoyuna, moda ile ilgilenen ve fotoroman yayını yapan gazeteler de daha çok genç kızlara ve kadınlara hitap etmektedir (Kazanc1, 2007: 348). Bu bilgi 1şığında hedef kitleyi tanımanın ne kadar önemli olduğu anlaşılmaktadır. Mesajların ilgili hedef kitleye 


\section{TÜRKIYE MESLEKI VE SOSYAL BILIMLER DERGISI}

Türkiye Mesleki ve Sosyal Bilimler Dergisi, Nisan 2021, Yıl: 3, Sayı: 5, 66-78.

Journal of Vocational and Social Sciences of Turkey, Apr 2020, Year: 3, No: 5, 66-78.

göre düzenlenmesiyle hem ekonomik olarak tasarruf edilmesi hem de mesajların hedef kitlede istenildiği şekilde yankı bulması sağlanmış olacaktır.

Dergiler: Halkla ilişkiler aracı olarak gazetelerin sahip oldukları nitelikler dergiler içinde aynen kabul edilmektedir. Dergilerde zaman aralığının çok olması ve gazeteden farklı haber anlayışı nedeniyle genellikle sütun ve yer sıkıntısı bulunmaktadır. Dolayısıyla halkla ilişkiler birimleri, dergilerin ana konularını dikkate alarak ve yer sıkıntılarını hesaba katarak bu araçtan yararlanmak durumundadırlar (Kazanc1, 2007: 354).

Broşürler: Broşürler küçük bir dergi boyutunda ve çoğunlukla az sayfalı basılan bir tanıtma aracıdır. Broşürler daha çok kurumları tanıtan temel bilgileri içermekte ve kurumun bugüne kadar olan gelişmelerini grafik ve tablo üzerinde göstermektedir. Broşürler kurumlara ziyarete gelen ve gezen kişilere, ayrıca kurumu tanımak isteyenlere verilmektedir (Sabuncuoğlu, 2001: 141).

Afiş, İlan Tahtası ve Bültenler: İşletmelerin belirli bölgelerine koyulan veya asılan bu araçların en mühim özelliği verilmek istenilen habere, alakalı alakasız herkesin ilgisini çekmektir (Sabuncuoğlu, 2001: 141). Afiş, kuruluşu hedef birimlerle genel ortamlarda buluşturmak için yararlanılan iletişim ürünü olmanın yanında, kısa ve sade mesaj yazısıyla, etkileyici grafik tasarımın ahenginden oluşmaktadır (Bıçakçı, 2006: 128).

Basın Bültenleri: Kurum içine ve/veya dışına yönelik olarak hazırlanabilen, geniş kitlelere ulaşma imkânı sağlayan basın bültenleri, kuruma ait haberleri kurum çalışanlarına ya da kurum dışında kalan ilgili kişi veya kuruluşlara (hükümet, kamu görevlileri, müşteriler, bayiler, dağıtımcılar vb.) aralıksız şekilde ulaştırmayı amaçlamaktadır. Basın bültenleri, on beş günlük, aylık, iki aylık olarak belli bir takvime uyularak yayınlanmaktadır.

Yıllık Raporlar: Kurumun içindeki veya dışındaki kişilere yönelik olarak hazırlanan ve işletmenin bir senelik çalışmalarını içeren iletişim araçlarıdır (Bıçakçı, 2006: 128).

\subsection{Sözlü Araçlar}

Yüz Yüze Konuşma: Sözlü iletişimde en çok kullanılan araç, konuşma ve yüz yüze görüşmedir. Halkla ilişkilerde yüz yüze görüşme, işletmeyi temsil eden kişiler ile halk arasında yapılan konuşmaları ifade etmektedir (Sabuncuoğlu, 2001: 143). Bu konuyu düzenleyen ve planlayanlar ise yöneticiler, işçiler veya uzmanlardan oluşan ekiptir. Karşı taraf ise tüketiciler, sendikalar ve bankacılardan oluşan kuruluşlardır (İşşi, 2002: 47).

Konferans, Seminer, Toplantı ve Panel: Konferans; yapılacak yeri, tarihi, konu ve konuşmacısı önceden açıklanan, genellikle bir kişinin konuşmacı olarak katılım sağladığı, herkese açık toplantılardır (Tutar ve Y1lmaz, 2012: 211). Seminerler, belirli konularda katılanların aydınlatılmalarını, güncel sorunların tanıtılmasını ve tartışılmasını sağlamaktadır. Halkla ilişkiler açısından toplantılar bilgi verme, değerlendirme veya bilgi alma maksadıyla yapılmaktadır. Katılanlar karşılıklı fikirlerini söyleyerek bilgi alış-verişinde bulunmaktadırlar. Ayrıca işletme, katılanlara toplantı esnasında en tatmin edici bilgileri sunmaktadır. Toplant daha az sayıda kişinin katıldığı ve karşılıklı görüşmelerin yapıldığı iletişim aracıdır (Sabuncuoğlu, 2001: 146-147). Panel ise, toplumun büyük kesimini alakadar eden ve üzerinde uzlaşma sağlanmasında fayda beklenilen, belirli bir mevzunun birden çok konuşmacı tarafından dinleyicilerin önünde münakaşa edildiği toplantı türüdür (Tutar ve Y1lmaz, 2012: 211).

\subsection{Görsel ve İşitsel Araçlar}

Radyo: Radyo, erişilmek istenilen hedef kitleye ucuz bir şekilde ulaşmayı sağlamaktadır (Gürbüz ve İnal, 2004: 92). Radyonun görselliği kullanamaması iletileri sesle sinırlandırmaktadır. Radyo, kitlelere haberi en hızlı ulaştıran iletişim aracı olmasının yanında, düş gücünü harekete geçirmekte ve aynı zamanda başka bir işle ilgilenme imkânı sağlamaktadır (Eroğlu, 2006: 175). Radyonun sunduğu bu özellik, bireyleri özgür k1lmakta ve televizyon gibi saatlerce kendine hapsetmemektedir. 
Türkiye Mesleki ve Sosyal Bilimler Dergisi, Nisan 2021, Yıl: 3, Sayı: 5, 66-78.

Journal of Vocational and Social Sciences of Turkey, Apr 2020, Year: 3, No: 5, 66-78.

Halkla ilişkiler uzmanları çeşitli demografik özelliklere sahip geniş kitlelere ulaşma olanağı sağlayan radyodan; haber bülteni, röportaj, sohbet programı, açık oturum, kamusal duyuru gibi farklı şekillerde faydalanmaktadırlar (Peltekoğlu, 2004: 216).

Televizyon: Televizyonların izleyici kitlesi oldukça geniş ve karmaşık yapıya sahiptir. Televizyon izleyicilerini dar bir grup altında sıralamak mümkün değildir. Genç, yaşlı, eğitimsiz, kentli, köylü, herhangi bir partiyi destekleyen vb. geniş kitleler televizyon izlemektedir (Devran, 2004: 242).

Yapılan araştırmalar televizyon izleyicilerinin sayısının hem gazete okurları hem de radyo dinleyicilerinden fazla olduğunu ortaya koymaktadır. İzleyici sayısının çok olması, televizyonun etkisini artıran unsurlardan birisidir (Bektaş, 2002: 112). Televizyonun asıl etki gücü, daha yaygın alana seslenebilmesinden ve görüntüyle metnin birleşmesinin "gerçeğe" daha yakın olmayı hissettirmesinden kaynaklanmaktadır. Bu sebeple canlı yayınlar, izleyicide "tanık olma", kendini olay örgüsünün içinde hissetme duygusunu sağlamaktadır (Özerkan ve İnceoğlu, 1997: 81).

Halkla ilişkiler aracı olarak televizyonda, radyoda olduğu gibi haber bültenlerinden, sohbet ve tartışma programlarından yararlanılmaktadır. Stüdyoda gerçekleştirilen sohbet ve tartışma programları maliyetin az olması sebebiyle televizyon istasyonları tarafindan tercih edilmektedir. Radyodan farklı olarak görselliğin büyük önem taşıdığ1 televizyon programına katılacak konuşmacılar istenen mesaj1 iletebilmek ve etkin olabilmek amacı taşımaktadırlar (Peltekoğlu, 2004: 221).

Sergi ve Fuarlar: İşletmelerin gelişim sürecini, yeni ürünlerini, yeni düzenlemelerini tanıtmak amacıyla yürütülen etkinliklere sergi denilmektedir. Sergiler, işletmeler ile çevresi arasında etkileşimli iletişim kurmanın etkin bir aracıdır (Tutar ve Yılmaz, 2012: 213). Sergi ve fuarlarda bulunmak, işletmelere ürün ya da hizmetin tanıtımı, pazarı genişletme olanağı sağlamasının yanında, rakip işletmelerin bulundukları konumu göstermesi yönüyle de önem taşımaktadır (Peltekoğlu, 2004: 271). $\mathrm{Bu}$ bakımdan halkla ilişkilerde kullanılan sergi ve fuarların amaçları arasında; kuruluşun tanıtımını yapmak, mevcut müşterilerle iletişim kurarak ilgilerini artırmak, yeni satış alanları oluşturmak, kuruluşun yeni ürün ve hizmetlerini tanıtmak, yetkililerle iletişim kurmak ve sipariş imkânı sağlamak yer almaktadır (Wood, 1992: 79).

Yarışmalar: Hedef kitlelerin desteğini sağlamak için düzenlenen iletişim ortamları olan yarışmalar, kurum içinde ve dışında kazanılması düşünülen hedef kitleleri ilgilendiren biçimde yapılmaktadır (Bıçakçı, 2006: 134). Ödüllü olmak zorunda olan yarışmalar, ödül sayesinde kitlelerde gerek ilgiyi artırmakta gerekse de yarışmaya daha ciddi bir görünüm kazandırmaktadır. Yarışmaların hem açılması hem de kazananların ilan edilmesi ve ödüller kesinlikle radyo, televizyon ve gazetelerle kamuoyuna duyurulmalı ve bu duyurular belirli periyotlarla tekrarlanmalıdır (Kazanc1, 2007: 262).

Festival ve Şenlikler: Ülke halkının dikkatini bir bölgeye veya kente çekmek için uygulanan halkla ilişkiler tekniklerinden biri olan festivallerin amacı, büyük insan gruplarının ilgisini belli bir bölgeye çekmektir (İşçi, 2002: 50). Kaplıca haftası, kiraz bayramı, kayısı şenliği gibi değişik adlar altında düzenlenebildiği gibi, yağlı güreşler, horoz ya da deve güreşleri, türlü yarışmalarla, panayır ve tiyatrolarla, müzik şölenleri ve öteki toplumsal faaliyetlerle renklendirilen festivaller ve şenlikler, küçük ve orta ölçekteki kentlerin halkla ilişkiler uygulamalarının birer simgesi durumuna gelmişlerdir (Kazanc1, 2007: 362). Ulusal ve uluslararası boyutta gerçekleştirilen festivaller, iletişim araçlarının katkısıyla geniş kitlelere ulaşmakta ve festivaller aracılığıyla hem festivali düzenleyen kurum veya kuruluşların hem de yörenin prestiji artmakta, ekonomik yaşamın hızlanması sağlanmaktadır (Bıçakçı, 2006: 134).

\section{HALKLA İLIŞKILER ve MEDYA İLIŞKIILERI}

Halkla ilişkiler uygulamasının temelinde kitle iletişim araçları ile yani medya aracıllğıyla olumlu tanıtım yapmak yatmaktadır (Seitel, 2016: 170). Medya ilişkileri, bir kuruluşun menfaat ve amacına uygun olarak, kuruluşun tanıtımı amacıyla medyayla ilişsi kurma faaliyetidir (Erdoğan, 2014: 196). 
Halkla ilişkiler açısından azami seviyede pozitif içerikte yayını amaçlayan medya ilişkileri içinde basınla ilişkiler önemli yer tutmaktadır (Peltekoğlu, 2004: 189). Halkla ilişkiler açısından gerçekleştirilen çalışmaların önemli boyutunu basınla ilişkiler kurup, sürdürme gayretleri oluşturmaktadır (Biber, 2006: 96).

Medya, bilginin ve haberin hızlı iletilmesi, görsel, işitsel ve metin olarak sunulması, her türden hedef kitlenin ilgilenebileceği bir yap1 göstermesi nedeniyle günümüzde değiştirici ve dönüştürücü kimliğiyle kabul edilmekte ve kurumlar için vazgeçilmez bir güç olarak nitelendirilmektedir (Vural ve Bat, 2013: 280). Medyanın sahip olduğu bu özellikler hedef kitlesini etkilemek, onlarda anlayış ve sempati yaratmak isteyen halkla ilişkilerin en çok aradığı ve kullanmak istediği özellikler olmaktadır. Bu nedenle halkla ilişkilerin medyayla ilişkisi oldukça önemlidir (Canöz, 2010: 21).

Medya ile ilişkinin temel taşını bilgi oluşturmaktadır. Medyanın gücü bilgiyi kitlelere ulaştırabilmesinden ve kitleleri etkileyebilmesinden kaynaklanmaktadır (Aydede, 2002: 124-125). Kamuoyu üzerindeki etkisi bu kadar güçlü olan medyanın halkla ilişkiler açısından önemi yadsınamaz düzeydedir. Medya ile olumlu ilişkilere sahip olan kurumlar kendi lehine büyük avantajlar sağlarken, bunun tersi olarak negatif ilişkiler ise kurumları, dönüşü mümkün olmayan krizlerle karşı karşıya getirebilmektedir. $\mathrm{Bu}$ sebeple halkla ilişkiler uzmanlarının basının güvenini kazanabilmeleri gerekmektedir (Göksel, 2010: 114). Ayrıca kurumun medyayı takip etmesi sürecinde kurumla alakalı haberlerin medyada yer bulan ilgili halkla ilişkiler birimlerince titizlikle ele alınması sağlanmalıdır (Tarhan ve Bakan, 2013: 60).

Halkla ilişkiler uzmanları, görev yaptıkları kurumun stratejik iletişim amaçlarını bilmeli, bunları benimsemeli ve basınla bu sorumluluk bilinciyle bilgi paylaşmalıdır. Halkla ilişkiler uzmanları gerek kendi kurumlarını tanıyarak gerekse de medyadaki paydaşlarını tanıyarak etkili ve doğru iletişim kurabilirler (Adıgüzel, 2017: 30). Bu bakımdan halkla ilişkiler görevlilerinin davranışlarından başka, medyayla ilişkileri geliştirmek için düzenlenen birtakım etkinlik ve uygulamalar vardır. Bu etkinlik ve uygulamalar; basın bildirisi/bülteni, basın toplantıs1/konferansı, basın resepsiyonu, basın gezisi, basın röportaj1/mülakat1, fotoğraf ve internettir (Canöz, 2010: 23).

Basın Bültenleri / Bildirileri: Her kuruluş ekonomik başarılarını, gerçekleştirdikleri çalışmalarını, düzenledikleri toplumsal faaliyetlerini tanıtarak halkın güvenini kazanmak ister. Kurumlar bunları yaparken sadece kendilerini tanıtma maksadıyla değil, aynı zamanda beğendirme ve toplum nezdinde kurumun amaçlarına uygun bir imaj oluşturma niyeti taşımaktadırlar. Kuruluşlar basın aracılığıyla amaçlarını gerçekleştirmek için neler yaptıklarını geniş kitlelere en masrafsız yoldan iletmeyi sağlayabilirler (Özüpek, 2003: 88).

Bültenler, kuruluşların tanıtımında ve iç ilişkilerinde tercih edilen, ilgili kişilerin devamlı bilgilenmesine yarayan çok sayfalı mektuplardır. Bültenlerin 200'den fazla çeşidi olması nedeniyle kurumun yapısına uygun olan çeşit tercih edilmeli ve çoğaltılarak daha çok kişiye ulaşılması amaçlanmalıdır (İşçi, 2002: 44).

Basın bülteni hazırlanırken öncelikle basın bülteninin doğrudan gönderilen medyada yayımlanabileceği düşüncesi temel alınmalı ve haber olduğu unutulmamalıdır. Ayrıca bir basın bülteninin " $5 \mathrm{~N}$ ( $\mathrm{Ne}$, Neden, Nasıl, Nerede, Ne zaman) 1K (Kim?)" sorularına yanıt vermesi gerekmektedir (Vural ve Bat, 2013: 285).

Basın Toplantısı / Konferansı: Yazılı ve sözlü basının çalışanlarına açık olan ve önemli haberlerin kitle iletişim araçlarına iletildiği tanıtımlar olan basın toplantıları (İşçi, 2002: 45), basın bildirisiyle anlatılamayacak kadar mühim ve detaylı konular için düzenlenmelidir. Basın toplantısı daha başlamadan varsa konuyla alakalı broşür, doküman, resim gibi materyaller basın çalışanlarına bir dosya şeklinde verilmelidir (Biber, 2006: 101). Basın toplantısının istenen etkiyi oluşturulabilmesi için düzenlenme biçiminin çok dikkatli planlanması gerekmektedir. Bu sebeple öncelikle katılımcı 
Türkiye Mesleki ve Sosyal Bilimler Dergisi, Nisan 2021, Yıl: 3, Sayı: 5, 66-78.

Journal of Vocational and Social Sciences of Turkey, Apr 2020, Year: 3, No: 5, 66-78.

sayısının önceden bilinmesi organizasyonun başarılı geçmesi açısından büyük fayda sağlayacaktır (Canöz, 2010: 29).

Basın Resepsiyonu: Basın resepsiyonları, basın toplantılarından daha ayrıntılı ve planlı şekilde yürütülmektedir. Toplantı yeri, davetli listesi, yiyecek servisi, konuşma metni gibi uygulamalara ilişkin hazırlıklar çok önceden başlayıp resepsiyondan önce hazır hale getirilmelidir (Peltekoğlu, 2004: 206). Basın resepsiyonunda amaç, basın mensuplarıyla daha sıcak ve samimi ilişkiler kurmak, kuruluşla ilgili olumlu haberlerin basında daha çok ve istenildiği gibi yer almasını sağlamak, yeni çıkan bir ürünü tanıtmak, yeni konuları duyurmaktır (Canöz, 2010: 27).

Basın Gezisi: Basın gezileri toplumsal bir konunun basının dikkatinin çekilmesi için düzenlenmektedir (Vural ve Bat, 2013: 291). Katılanlar açısından bir maliyet gerektiren basın gezilerine katılımın istenen düzeyde gerçekleşebilmesi haberin önemi ile doğrudan ilişkilidir (Peltekoğlu, 2004: 208). Dolayısıyla basın gezileri iki sebepten dolayı yapılmaktadır. Birincisi verilecek haberin bir yerle ilgili olması (bir fabrika, bir sergi, bir baraj veya bir köprünün açılışı, temel atılması, ziyareti gibi etkinliklerde); ikincisi de olayın gerçekleștiği yer ile ilgili olması durumunda (Hasankeyf'in sular altında kalması, Tuz Gölü’nün kirlenmesi, Haliç Körfezi'nin temizlemesi vb. nedenlerle) basın seyahati gerçekleştirilmektedir (Canöz, 2010: 35).

Basın röportajı / Mülakatı: Basın röportajı, basın mensuplarının kuruluşla ilgili herhangi bir konuda bilgi almak istediklerinde kuruluşun iletişim sorumlusuyla veya kuruluş adına açıklama yapmaya yetkili bir personelle görüşme yapmak için girişimlerde bulunmasıdır. Basın röportajlarında halkın, kuruluş tarafından belli konularda bilgilendirilmesi gerekmektedir (Biber, 2006: 101). Bu bağlamda halkla ilişkiler çalışanlarının birincil görevi medya ile yapılacak röportajları organize etmektir (Seitel, 2016: 191). Genellikle basın yayın kuruluşları tarafından yapılmak istenen röportajlar, doğru kullanıldığında kurum için oldukça faydalı olmaktadır. Röportaj yapan kişi kurum hakkındaki bilgiyi doğrudan medya temsilcisine aktarabilmekte, muhabir ise doğrudan bilgiye erişme imkânı yakalamaktadır (Vural ve Bat, 2013: 292).

Fotoğraf: Fotoğrafin bir konuyu anlatma gücü onu gazetelerin, dergilerin, broşürlerin ve işletme gazetelerinin vazgeçilmez unsuru haline getirmektedir (Canöz, 2010: 40). Fotoğrafin verilmek istenen mesajı iletme özelliği olduğundan basın bülteni ile beraber fotoğrafın medyaya ulaştırılması esnasında gereken şey, ana gayenin iletişim olduğunun unutulmaması gerektiğidir (Peltekoğlu, 2004: 253).

İnternet: İnternet coğrafi sınırları kaldırmanın yansıra işitsel ve görsel öğeleri bünyesinde barındırmakla toplumların eş zamanlı iletişim kurmalarını sağlamaktadır (Alikılıç, 2011: 4). İnternet geleneksel iletişim araçlarıyla kıyaslandığında, iki yönlü ve senkronik iletişime imkan sağlaması, süratli olması, az maliyet gerektirmesi gibi önemli avantajlara sahiptir (Bakan, 2010: 373374).Dolayısıyla internet, medyaya hem iletişim açısından yeni bir boyut kazandırmış hem de iletişim sürecine önemli değişiklikler ve yenilikler katmıştır. Bu bağlamda geleneksel kitle iletişim araçları ve internetin sağladığı yeni medya araçları arasındaki farklar şöyle ifade edilmektedir.

Tablo 1. Geleneksel Kitle İletişim Araçları ve Yeni Medya Karşılaştırılması

\begin{tabular}{|l|l|}
\hline \multicolumn{1}{|c|}{ Geleneksel Kitle İletişim Araçları } & \multicolumn{1}{c|}{ Yeni Medya (İnternet) } \\
\hline Yerel ve bölgesel hedef kitleler & Geniş ölçekte konu, ihtiyaç ve ilgili hedef kitleler \\
\hline Eşik bekçileri ve editörler (hiyerarşik yapı) & Birden çok kişiye ve çok kişiden kişiye (yatay) \\
\hline Dolaylı ve tek yönlü yapılanma & Etkileşimli geribildirim ve tartışma \\
\hline Sınırlı sayfa ve frekans & Zaman ve frekans engeli yok, geniş ölçekte bilgi \\
\hline Geniş izleyici kitlesine yönelik & Müşteriye özgü/dar hedef kitleye yönelik \\
\hline Geribildirim çok yavaş, zor ve sınırlı boyutta & E-posta ve çevrimiçibağlantıyla hızlı ve kolay \\
\hline Kurumsal mülkiyete bağlı yapı & Bireylerinçabasına dayalı yapı \\
\hline Belirli format, zaman ve mekân & Esnek formatta ve akıcı multimedya \\
\hline
\end{tabular}

Kaynak: (Tarhan, 2007: 77) 
Tablo incelendiğinde, geleneksel kitle iletişim araçları ile yeni medya (internet) arasında belli farklar olduğu göze çarpmaktadır. Genel olarak geleneksel kitle iletişim araçlarında kısıtlı sayfaların olduğu, geniş (çeşitli) izleyici grubuna yönelik yapının söz konusu olduğu, geribildirim (feedback) unsurunun yavaş işlediği görülmektedir. Diğer taraftan yeni medyanın (internet) ise spesifik kitleye yönelik olduğu, zaman engeli olmadan işleyen bir sürecin hâkim olduğu, feedback unsurunun kolay, etkileşimin ve paylaşımın da hızlı olması söz konusudur.

Kuruluşlar basına bilgi vermede basın dosyaları, basın bildirileri ve basına yönelik etkinliklerden yararlanırken, günümüzde bu bilgiler internet ortamındaki web sayfalarından da duyurulabilmektedir. $\mathrm{Bu}$ sayede basında yer alması istenen bilgiler en hızlı şekilde basına ulaştırılmış olurken, etkinliğe gelmeyen/gelemeyen basının da konuya birinci ağızdan ulaşma imkânı, en zahmetsiz ve maliyetsiz şekilde gerçekleşmiş olmaktadır (Canöz, 210: 41).

İnternetin bir ürünü olan elektronik posta (e-mail), mesaj iletiminde önemli bir zaman tasarrufu sağlamasının yanında, kişilere bilgiye ulaşabilme ve interaktif haberleşme imkânı sağlamaktadır (Peltekoğlu, 2004: 258). Ayrıca basın bültenlerinin elektronik posta vasıtasıyla muhabir ve editörlere ulaştırılması, bu ilgili kişilerin bilgisayarlarına not ettikleri yazı üstünde düzeltme ve değişiklik yapabilme imkânı sağladığından medya çalışanlarınca tercih edilen bir metot olarak ilgi çekmektedir (Tarhan, 2013: 233).

İnternet, geleneksel medya ilişkilerinin işleyişinde, araçlarında, etkinliklerin yapılmasında, iletişim kurulan kişilerin çeşitlenmesinde ve iletişim kanallarının yapısında çeşitli değişiklikler meydana getirmiştir. $\mathrm{Bu}$ farklıları geleneksel medya ilişkileri ve günümüz medya ilişkileri açısından değerlendirmek medyanın değişimini anlamak açısından fayda sağlayacaktır.

Tablo 2. Geleneksel Medya İlişkileri ve Günümüz Medya İlişkileri Arasındaki Farklar

\begin{tabular}{|c|c|c|}
\hline Kategoriler & Geleneksel Medya İlişkileri & Günümüzde Medya İlişkileri \\
\hline \multirow{5}{*}{ Araçlar } & Basın bülteni & Çevrimiçi basın bülteni, basın odaları \\
\hline & Videokaset & $\begin{array}{l}\text { Video paylaşım sitelerindeki linkler (bağlantı } \\
\text { adresleri) }\end{array}$ \\
\hline & Fotoğraf & $\begin{array}{l}\text { Fotoğraf paylaşım sitelerindeki linkler, taşıyıcı } \\
\text { bellek, cd }\end{array}$ \\
\hline & Basin kiti & Çevrimiçi basın kiti \\
\hline & $\begin{array}{l}\text { Basin kitiyle verilen hediyeler, } \\
\text { kuponlar }\end{array}$ & Çevrimiçi hediyeler ve kuponlar \\
\hline Etkinlikler & $\begin{array}{l}\text { Basin toplantıları, basın gezileri, } \\
\text { basın turları, basın kokteylleri }\end{array}$ & $\begin{array}{l}\text { Etkinlikler (Eventler), ürün lansmanları, tematik } \\
\text { etkinlikler, ziyaretler }\end{array}$ \\
\hline $\begin{array}{l}\text { İletişim Kurulan } \\
\text { Kişiler }\end{array}$ & $\begin{array}{l}\text { Haber müdürleri, yazı işleri } \\
\text { müdürleri, ilgili muhabirler }\end{array}$ & $\begin{array}{l}\text { Haber sitelerindeki ilgili kişiler, ilgili bloggerlar, } \\
\text { çevrimiçi kanaat önderleri, çevrimiçi toplulukların } \\
\text { yöneticileri }\end{array}$ \\
\hline $\begin{array}{l}\text { Kontrol Edilebilir } \\
\text { İceriğin Paylaşıldığı } \\
\text { İletişim Kanalları } \\
\end{array}$ & $\begin{array}{l}\text { Kurumsal web sitesi, kurumsal } \\
\text { bülten, kurumsal reklam, özel } \\
\text { programlar }\end{array}$ & $\begin{array}{l}\text { Etkileşimli web sitesi, kurumsal bloglar, sosyal } \\
\text { ağlardaki profil sayfaları, hesaplar, gruplar. }\end{array}$ \\
\hline $\begin{array}{l}\text { Kontrol Edilemeyen } \\
\text { İçeriğin Paylaşıldığı } \\
\text { İletişim Kanalları }\end{array}$ & Televizyon, radyo, gazete, dergi & $\begin{array}{l}\text { Geleneksel iletişim mecraları, haber siteleri, sosyal } \\
\text { ağlar, video ve fotoğraf paylaşım siteleri, bloglar }\end{array}$ \\
\hline
\end{tabular}

Kaynak: (Onat, 2014: 10)

Sosyal Medya: Sosyal medya denildiğinde genel olarak Instagram, Twitter, Facebook, YouTube gibi iletişim araçları düşünülmektedir. Bu sosyal mecraların her birinin kendine göre kullanım amaçları vardır ve kişilere bu kullanım amaçlarına göre imkânlar sunmaktadırlar. Bireysel ve kitlesel anlamda paylaşım firsatı sunan bu mecralar (Silsüpür, 2016: 730-731) sadece eğlence odaklı işlev görmemekte, aynı zamanda toplumun her kesiminden insan tarafindan kullanılmakta ve istenilen veriler, bilgiler, paylaşımlar yapılmaktadır. 
Sosyal medya halkla ilişkiler faaliyetlerine; yeni paydaşlar, sosyal paydaşlarla aracısız iletişim ve etkileşim, mesajların yayılması, hedef kitlelerde işbirliği, geri bildirim (feedback) sağlama ve düzeltme, katılım ve adaptasyon, ağ oluşturma, güven, kurumsal itibar (Alikılıç, 2011: 17-19) sağlamaktadır. Dolayısıyla halkla ilişkiler gerek geleneksel kitle iletişim araçları gerekse de sosyal medya sayesinde hedef kitlelerle etkili ve verimli iletişim kurmada önemli iletişim araçları olarak görülmektedir. Bu bağlamda halkla ilişkilerin olmazsa olmazı olan doğruluk, inandırıcılık, iki yönlü iletişim süreci sosyal medya platformları aracılığıyla gerçekleştirilmekte ve böylece zaman kaybının da önlenerek hedef kitlede güven oluşturulmaktadır.

\section{SONUÇ}

Halkla ilişkiler hem geleneksel kitle iletişim araçları hem de internet ve sosyal medya sayesinde hedef kitlelere ulaşmakta ve mesajlarını iletmektedir. Medya; bilgilendirme, aydınlatma, haber olma, dikkat çekme gibi işlevleri sağladığı için halkla ilişkiler sürecinde hedef kitlelerle olan iletişimde önem taşımakta ve dikkat çekmektedir. Bu sebeple halkla ilişkiler açısından medya, gerek kullanılan araç ve yöntemler gerekse de hedef kitlelerle kurulan ilişkide köprü görevi taşımaktadır.

Halkla ilişkilerde kullanılan araç ve yöntemlerden yazılı-basılı araçlar, sözlü araçlar ve görsel-işitsel araçlar önemli ve hedef kitleler nezdinde etkilidir. Bu araçlar medyayla ilişkileri kurmada ve geliştirmede önemli olanaklar sağlamaktadır. Medya ile kurulacak ilişkilerde gelişen teknolojiyle birlikte kullanılacak araçlar kitleler açısından hafızalarda kalıcı olacaktır. $\mathrm{Bu}$ anlamda halkla ilişkiler ve medya arasında sıkı bir ilişki söz konusudur. Halkla ilişkiler, medya endüstrisinin tam odak noktasındadır. Çünkü hızlı gelişen ve ilerleyen iletişim teknolojileri kurumlara ve insanlara her an bilgiye erişme fırsatı sağlamaktadır. Medya işin görünen kısmında, yani vitrinindedir. Dolayısıyla işletmelerin hedef kitleleri karşısında kalıcılığı sağlamak, pozitif imaj oluşturmak için halkla ilişkiler çalışmalarına son derece önem verip, etkinliklerini ve görünürlüklerini medya aracıllğıyla kitlelere duyurmaları, göstermeleri gerekmektedir.

Teknolojinin gelişmesiyle birlikte internetin kullanılmaya başlanması dolayısıyla iletişim araçlarının ve yeni iletişim teknolojilerinin süratle gelişmesiyle, sosyal mecralar bireylerin kullanım alanlarına girmiştir. Bireyler bu sosyal mecralara kolay adapte olmakta ve aktif şekilde bu alanları kullanmaktadirlar.

Günümüz şartlarında halkla ilişkiler faaliyetleri, geleneksel iletişim araç ve yöntemleri dışında artık sosyal medya araçlarıyla çeşitlenmiş ve iletişim bu araçlarla hızlı şekilde sağlanmaya başlanmıştır. Bu araçlar geleneksel kitle iletişim araçlarının anındalık, hızlılık, etkileşim gibi birtakım eksikliklerini gidererek birçok hedef kitleye ulaşmayı sağlamaktadır. Bu sebeple halkla ilişkiler uzmanları artık bu mecraların avantajlarından yaralanarak hedef kitlelere ulaşmalı ve bu mecralardan kitlelere seslenmelidir.

Halkla ilişkiler ve medya arasında olumlu gelişen, ilerleyen ve büyüyen bir iletişimin hâkim olması gerekmektedir. Halkla ilişkiler ve medya birbirine ihtiyaç duyan, karşılıklı irtibat sağlaması gereken ve koordinasyon isteyen bir süreçtir. Bu süreç ister vatandaşın yararına bir açılış olsun, ister bir ürünün tanıtımı olsun, ister bir doğa olayına dikkat çekmek olsun fark etmemektedir. Halkla ilişkiler açısından önemli olan bunun kitlelere duyurulması, haber edilmesi; medya açısından ise haber malzemesi sağlayıp, izleyicilere/ okurlara/ dinleyicilere aktarılmasıdır. Böylece haberin kitlelere duyurulması sağlanıp kamuoyu kısa sürede bilgilendirilmiş olmaktadır.

$\mathrm{Bu}$ çalışma genel olarak halkla ilişkiler ve medya arasındaki iletişimde kullanılan geleneksel araç ve yöntemlere odaklanmıştır. Dolayısıyla bundan sonra yapılacak çalışmalarda halkla ilişkiler ve spesifik olarak sosyal medya konusu ele alınarak halkla ilişkiler ve medya arasındaki diyalogun bu mecralarla nasıl sağlandığına bakılması faydalı olacaktır. 


\section{KAYNAKÇA}

Adıgüzel, Y. (2017). “Geleneksel Medya ile İlişkiler”, İ. Vural ve U. Eriş (Ed.), Medya İlişsileri, içinde (26-45), Eskişehir: Anadolu Üniversitesi Açıöğretim Fakültesi Yayınları.

Alikılıç, Ö. A. (2011). Halkla İlişkiler 2.0: Sosyal Medyada Yeni Paydaşlar, Yeni Teknikler,Ankara:Elif Yayınevi.

Asna, A. (2006). Kuramda ve Uygulamada Halkla İlişkiler, İstanbul: Pozitif Yayınları, İstanbul.

Aydede, C. (2002). Teorik ve Uygulamalı Halkla İlişsiler Kampanyaları, İstanbul: Mediacat Kitapları, İstanbul.

Bakan, Ö.(2011). "Halkla İlişkiler Aracı Olarak İnternet", A. Kalender ve M. Fidan (Ed.), Halkla İlişkiler, içinde (373-389), Konya: Tablet Yayınevi.

Barry, A. (2003). Halkla İlişkilerin Gücü, A. Ö. Steidle (Çev.), Ankara: Kesit Tanıtım Ltd. Şti.

Bektaş, A. (2002). Siyasal Propaganda: Tarihsel Evrimi ve Demokratik Toplumdaki Uygulamaları, İstanbul: Bağlam Yayıncilık.

Bıçakçı, İ. (2006). İletişim ve Halkla İlişkiler: Eleştirel Bir Yaklaşım, İstanbul: Mediacat Yayınları.

Biber, A. (2006). Sivil Toplum Örgütlerinde Halkla İlişkiler, Ankara: Nobel Yayın Dağıtım.

Canöz, K. (2010). Sağlık Kuruluşlarında Halkla İlişkiler Uygulamaları, Konya: Palet Yayınları.

Cutlip, S. M., Center, A. H. ve Broom, G. M. (1994). Effective Public Relations, New Jersey: Prentice-Hall, Englewood Cliffs.

İşçi, M. (2002). Halkla İlişkiler, İstanbul: Der Yayınları.

Çobanoğlu, Ş. (2007). Suskunluk Sarmalı ve Siyasal İletişim, İstanbul: Fide Yayınları.

Devran, Y. (2004). Siyasal Kampanya Yönetimi: Mesaj, Strateji ve Taktikler, İstanbul: Odak İletişim.

Erdoğan, İ. (2014). Teori ve Pratikte Halkla İlişkiler, Ankara: Erk Yayınları.

Ertekin, Y. (1995). Halkla İlişkiler, Ankara: TODAİE Yayınları.

Göksel, A. B. (2010). Stratejik Halkla İlişkiler Yönetimi, Ankara: Nobel Yayın Dağıtım.

Gürbüz, E. ve İnal, M. E. (2004). Siyasal Pazarlama: Stratejik Bir Yaklaşım, Ankara: Nobel Yayın Dağııım.

Gürüz, D. (1993). Halkla İlişkiler Teknikleri, zmir: Ege Üniversitesi İletişim Fakültesi Yayınları.

Grunig, J. E. ve Hunt, T. (1984). Managing Public Rrelations, New York: Wadsworth/Thomson Learning.

Kalender, A. (2005). Siyasal İletişim: Seçmenler ve İkna Stratejileri, Konya: Çizgi Kitabevi.

Kalender, A. (2011). "Halkla İlişkiler: Kavramlar, Tanımlar ve Uygulama Alanları", A. Kalender ve M. Fidan (Ed.), Halkla İlişkiler, içinde (11-42), Konya: Tablet Yayınevi.

Kalender, A. (2012). "Kavram Olarak Halkla İlişkiler, Dünyada ve Türkiye'de Halkla İlişkilerin Tarihsel Gelişimi”, A. Z. Özgür (Ed.), Halkla İlişkiler, içinde (2-29), Eskişehir: Anadolu Üniversitesi Açıöğretim Fakültesi Yayınları.

Kazancı, M. (2007). Kamuda ve Özel Kesimde Halkla İlişkiler, Ankara: Turhan Kitabevi.

Kazaz, M. (2007). "Geleneksel Habercilikten İnternet Haberciliğine Geçiş Sürecinde Spor Basını”,Selçuk İletişim, 4(4), 220-229.

Kocabaş, F., Elden, M. ve Yurdakul, N. (2002). Reklam ve Halkla İlişkilerde Hedef Kitle. İstanbul: İletişim Yayınları.

Okay, A. ve Okay, A. (2002). Halkla İlişkiler: Kavram, Strateji ve Uygulamaları, İstanbul: Der Yayınları.

Onat, F. (2014). Dijital Çağda Halkla İlişkiler Yazarlı̆̆ı, Ankara: Nobel Yayınları.

Özerkan Ş. ve İnceoğlu Y. (1997). İletişimde Etkileme Süreci: Seçim Kampanyalarından Örneklerle, İstanbul: Metinler Matbaacilik.

Özüpek, M. N. (2003). “Halkla İlişkiler Faaliyetleri ve Basın”,Selçuk İletişim, 2(4), 84-89.

Peltekoğlu, F. B. (2004). Halkla İlişkiler Nedir, İstanbul: Beta Basım Yayım Dağıtım.

Sabuncuoğlu, Z. (2001). İşletmelerde Halkla İlişkiler, Bursa: Ezgi Kitabevi.

Seitel, F. P., (2016). "Medya", S. Ç. Mengü (Ed.), Halkla İlişkiler Uygulaması, içinde (167-198), Ankara: Nobel Yayıncilik.

Sezgin, M. (2007). Halkla İlişkiler: Meslek Yüksekokulları İçin Meb Ve Yök Uyumlu, Konya: Yücemedya Yayınları.

Silsüpür, Ö. (2016). "Siyasal İletişim Aracı Olarak Twitter'ın Kullanımı: 07 Haziran 2015 Genel Seçimi Üzerine Bir Çalışma", Gümüşhane Üniversitesi İletişim Fakültesi Dergisi, 4(2), 721-747.

Tarhan, A. (2007). "Halkla İlişkilerde Tanıma ve Tanıtma Aracı Olarak İnternet: Belediyelerin Web Sayfaları Üzerine Bir Analiz”, Selçuk İletişim, 4(4), 75-95.

Tarhan, A. (2013). "Halkla İlişkilerde Medyayla İlişsiler: Medya Çalışanlarının Görüşleri Üzerine Bir Saha Araştırması", E-Journal Of New World Sciences Academy, 8(2), 226-251.

Tarhan, A. ve Bakan, Ö. (2013). Belediyelerde Halkla İlişkiler ve Vatandaş Algısı, Konya: Literatürk Akademi. 


\section{TÜRKIYE MESLEKI VE SOSYAL BILIMLER DERGISI}

Türkiye Mesleki ve Sosyal Bilimler Dergisi, Nisan 2021, Yıl: 3, Sayı: 5, 66-78.

Journal of Vocational and Social Sciences of Turkey, Apr 2020, Year: 3, No: 5, 66-78.

Tengilimoğlu, D. (2001). Sağlık Kuruluşlarında Halkla İlişkiler, Ankara: Gazi Kitabevi.

Tengilimoğlu, D., Atilla, E. A. ve Bektaş, M. (2009). İşletme Yönetimi, Ankara: Seçkin Yayıncılık.

Tortop, N. (1998). Halkla İlişkiler, Ankara: Yargı Yayınevi.

Tortop, N. (2009). Halkla İlişkilere Giriş, Ankara: Nobel Yayın Dağıtım.

Tuna, M. ve Tuna, A. A. (2007). Kurumsal Kimlik Yönetimi, Ankara: Detay Yayıncılık.

Tutar, H. ve Yılmaz, M. K. (2012). İletişim: Genel ve Örgütsel Boyutlarıyla, Ankara: Seçkin Yayıncılık.

Vural, Z. B. A. ve Bat, M. (2013). Teoriden Pratiğe Kurumsal İletişim, İstanbul: İletişim Yayınları.

Wood, D. (1992). "Types of Media”, W. Howard (Ed.), The Practise of Public Relations, içinde, Oxford: Butterworth-Heinemann.

Yalın, B. E. (2006). “Siyasal İletişimin Reklam Boyutuna İlişkin Kuramsal Bir İnceleme”, İstanbul Üniversitesi İletişim Fakültesi Dergisi, 2(1), 167-180.

Yıldız, N. (2010). “Halkla İlişkilerde Kavramlar, Sınırlar, Sorunlar”, Selçuk İletişim, 6(2), 24-32. 


\section{PUBLIC RELATIONS AND MEDIA: A STUDY ON TOOLS AND METHODS EXTENDED ABSTRACT}

Public relations refers to planned communication in which accuracy is acted on internal and external target audiences and mutual understanding is developed in order to achieve corporate goals. Public relations activities, which contribute to the perception of the institutions in the minds of the target audiences, are also important in terms of communication to be established with the media. Dialogue should be built on solid bases by means of conveying characteristics such as sincerity, honesty and openness and adhering to these features In the communication that public relations units will establish with the media. In addition, the two-way communication to be established by the public relations units with the media contributes to both the public's introduction of itself to the public, and the public's knowledge and recognition of the institution.

In this study, it was aimed to determine the tools and methods used in the relationship of public relations with media by considering the discipline of public relations and the media, and a literature review was made in this direction. In regards to the theoretical development of public relations in Turkey, the study is important in terms of handling the tools, methods, activities and practices used in the relationship between public relations discipline and media. Communication, which is important among individuals and in social relations, forms the basis of public relations studies. Expressing the two-way communication process, public relations activities are an effective tool preferred by institutional management to achieve results. It is obligatory for every person and institution living in the society to realize their relations with their environment for a purpose and to maintain them in a planned way. For this reason, public relations, which is a managerial skill, undertakes an important task by using mass media, media and social media in establishing, regulating and developing this communication with the society. Having a great influence on individuals and organizations, media has an important and effective power in forming public opinion on certain issues and affecting the reaction of the public opinion in a positive or negative direction. For the news or information about the organization to be included in the media, News must be innovative, arousing, interest the audience, pay attention to the time of publication, and be sensitive to delivering it to the media on time with appropriate communication tools. Activities of public relations employees such as holding press conferences, drafting press releases, organizing trips to media workers are the natural result and indispensable of the connection with media relations.

Public relations takes advantage of the opportunities of developing technologies and maintains communication with target audiences in all channels. For this reason, it is important to know the tools that public relations use in their communication with the target audience. There are many tools that public relations use. These are divided into written and printed tools, verbal tools and audio-visual tools.

Knowledge constitutes the cornerstone of the relationship with the media. The power of the media lies in its ability to convey information and influence audiences. Having such a strong influence on public opinion, the importance of the media in terms of public relations is undeniable. While institutions having positive relations with the media provide great advantages in their favor, on the contrary, negative relations can confront institutions with irreversible crises. For this reason, public relations experts must be able to gain the trust of the press. In addition, in the process of monitoring the media by the institution, it should be ensured that the news that takes place in the media related to the institution is meticulously handled by the relevant public relations units. Apart from the behavior of public relations officers, there are some activities and practices organized to improve relations with the media. These activities and practices are press release / bulletin, press conference / conference, press reception, press trip, press interview / interview, photograph and internet. When today's communication technology is considered, social media providing the dialogue between public relations and media, should not be forgotten.

Public relations reaches the target audiences and conveys its messages both through the traditional mass media, the internet and the social media. Media is important and attracts attention in communication with target audiences in the process of public relations as it provides functions such as informing, enlightening, being news and attracting attention. For this reason, in terms of public relations, the media acts as a bridge in both the tools and methods used and the relationship established with the target audiences.

In the study, how the institutions can benefit from public relations in terms of internal and external target audiences, the tools and methods used in public relations, the activities used in establishing relations with the media are explained by a literature review. In this context, this study aims to contribute to the theoretical development of public relations in Turkey by linking public relations and media relations. 